\title{
Identification of low-abundance proteins via fractionation of the urine proteome with weak anion exchange chromatography
}

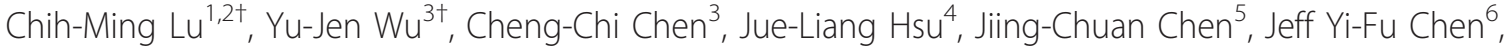 \\ Chun-Hsiung Huang ${ }^{1,7}$ and Ying-Chin Ko ${ }^{1,8^{*}}$
}

\begin{abstract}
Background: Low-abundance proteins are difficultly observed on the two-dimensional gel electrophoresis (2-DE) maps of urine proteome, because they are usually obscured by high-abundance proteins such as albumin and immunoglobulin. In this study, a novel fractionation method was developed for enriching low-abundance proteins by removing high-abundance proteins and progressive elution with salts of various concentrations.

Results: Stepwise weak anion exchange (WAX) chromatography, which applied DEAE-Sephacel resin with nonfixed volume elution, was used to fractionate urine proteome prior to performing 2-DE. Urine proteome was separated into four fractions by progressively eluting the column with $0 \mathrm{M}, 50 \mathrm{mM}, 100 \mathrm{mM}$, and $1 \mathrm{M} \mathrm{NaCl}$ solutions. Most of the heavy and light immunoglobulin chains appeared in the eluent. After the high-abundance proteins were removed, various low-abundance proteins were enriched and could be easily identified. The potential of this method for obtaining diversified fractionations was demonstrated by eluting the column separately with $\mathrm{Na}_{2} \mathrm{SO}_{4}$ and $\mathrm{MgCl}_{2}$ solutions. The 2-DE maps of the fractions eluted with these different salt solutions of identical ionic strength revealed markedly different stain patterns.

Conclusion: The present study demonstrated that this fractionation method could be applied for purposes of enriching low-abundance proteins and obtaining diversified fractionations of urine, and potentially other proteomes.
\end{abstract}

Keywords: Weak anion exchange chromatography DEAE-Sephacel, Fractionation, Proteomic, Urine

\section{Background}

Two-dimensional gel electrophoresis (2-DE) is a powerful technique for resolving a complex protein mixture. The analysis of urine proteins by 2-DE offers the potential for diagnosing and monitoring the progression of various diseases [1-5]. For example, analyses of urine proteins for the identification of disease biomarkers have been applied in bladder cancer [6,7], lung cancer [8], ovarian cancer [9], prostate cancer [10], membranous nephropathy [11], diabetic nephropathy [12], nephritic syndrome [13], and glomerular nephrotoxicity [14]. Although several 2-DE maps of human urine have

\footnotetext{
* Correspondence: ycko@kmu.edu.tw

+ Contributed equally

'Graduate Institute of Medicine, College of Medicine, Kaohsiung Medical

University, Kaohsiung, Taiwan

Full list of author information is available at the end of the article
}

been published [15-17], the resolution of these maps remains insufficient $\mathrm{s}$, and the demonstration of whole proteins in human urine remains a challenge. Immunoglobulin heavy and light chain proteins, as well as other high-abundance proteins, often obscure low-abundance proteins on 2-DE maps. An effective way to increase the resolution of urine proteome is to carry out a fractionation procedure prior to performing the 2-DE analyses. Certain fractionations have been widely used prior to 2-DE analysis in order to obtain more comprehensive information. For example, immunoaffinity subtraction chromatography [17], ligand beads [18], preparative electrophoresis and 2-DE [19], cation exchange chromatography in combination with a batch-absorption method [20], and finally, a commercially manufactured protein depletion kit to remove the six most abundant

\section{Biomed Central}


human plasma proteins (including albumin, transferrin, haptoglobin, immunoglobulin G, immunoglobulin A, and alpha-1 antitrypsin) [21] have all been utilized for this purpose.

There are many methods available for protein separation, and include, ammonium sulfate precipitation, gelfiltration, hydrophobic interaction chromatography, and ion exchange chromatography. Fractionation by ammonium sulfate precipitation depends on the solubility of protein. When the concentration (ionic strength) of the salt increases, solubility of the protein reduces. At a higher ionic strength, more proteins will be precipitated from the solution. Due to the inadequate protein resolution of ammonium sulfate precipitation, this method is usually only used in preliminary protein separation. While gel-filtration separates proteins based on the size of proteins, its main disadvantage is a limited loading capacity and low resolution associated with diffusion and turbulence. On the other hand, protein separation by hydrophobic interaction chromatography relies on differences in hydrophobic groups on the surface of solute. In this method, the hydrophobic groups of proteins bind the hydrophobic groups on the surface of an insoluble matrix. Further, ion exchange chromatography depends on charge-charge interaction between the fluid body proteins and the charges of the resin. In anion exchange chromatography, the binding ions have negative charge and the immobilized functional groups have positive charge. Once the solutes are bound to the gel, the column is washed with a starting buffer and the bound molecules are eluted off using a salt solution with various ionic strength. There are two main elution methods in chromatography: continuous gradient elution and stepwise isocratic elution. However, under equal volume of eluent, the best resolution can be obtained by using continuous gradient elution rather than stepwise isocratic elution. A low-abundance protein which is diluted in different fractions will reduce the possibility of a successful identification. To circumvent this problem, a stepwise, non-fixed volume, isocratic elution weak anion exchange (WAX) chromatography fractionation approach was investigated in this study. This modified WAX fractionation was comprised of four stepwise isocratic elusions. At each isocratic ionic strength, the elution process was continued until protein failed to be detected in the eluent. The aims of this study were to establish 2-DE maps with fine resolution and to enrich low-abundance proteins, thereby providing a platform for identification of potential disease biomarkers.

\section{Materials and methods}

\section{Collection of urine}

Urine samples were collected from 11 healthy males and 9 females between the ages of 18 and 54 years. Subjects with renal disorders or those being administered medication during the sample collection period were excluded. None of the females were menstruating at the time of sample collection. A $100 \mathrm{~mL}$ midstream urine sample was collected in the morning for each individual, and the samples were then combined together and supplemented with protease inhibitor cocktail to avoid proteolysis. Samples were centrifuged at $12,000 \mathrm{rpm}$ at $4^{\circ} \mathrm{C}$ to remove cell debris and insoluble solids. The final supernatants (2L) were then loaded to a Stirred Ultrafiltration Cell 8400 (Millipore, Billerica, MA, USA) and YM5 membrane (5000 molecular weight cut-off) to concentrate the solution and remove small interference molecules. The concentrated urine samples had a final volume of $50 \mathrm{ml}$, and were stored at $-80^{\circ} \mathrm{C}$ until further use. This protocol was approved by the Institute Review Board (Approval No. B09601020).

\section{Fractionation of urine proteome by non-fixed volume stepwise WAX}

A column $(5 \mathrm{~cm} \times 10 \mathrm{~cm})$ packed with 50 gram DEAESephacel (a weak anion exchanger from GE Healthcare) was equilibrated five times with $50 \mathrm{mM}$ Tris- $\mathrm{HCl}$ buffer prior to use. Twenty $\mathrm{ml}$ of concentrated urine samples were dialyzed overnight at $4{ }^{\circ} \mathrm{C}$ with $50 \mathrm{mM}$ Tris- $\mathrm{HCl}$ buffer (pH 8.0, 1 mM EDTA, 20 mM DTT). After removing the precipitate formed during dialysis by centrifugation $(8000 \mathrm{rpm})$, the sample was added to the column. First, the column was eluted by $3000 \mathrm{ml}$ of $50 \mathrm{mM}$ Tris- $\mathrm{HCl}$ buffer without salt at a flow rate of $40 \mathrm{ml} / \mathrm{hr}$ until no protein was detected in the eluent by Bradford dye assay. This process is distinct from fixed volume elution, in which some proteins could present in more than one fraction. A total of $3000 \mathrm{ml}$ of combined eluent was collected and concentrated to a volume of $50 \mathrm{ml}$ by using a Stirred Ultrafiltration Cell 8400 and a YM5 membrane. This sample was referred to as "unbound". Next, a solution of $50 \mathrm{mM} \mathrm{NaCl} / 50 \mathrm{mM}$ Tris- $\mathrm{HCl}$ buffer was used to elute the column, again until no protein was detected in the eluent, and a total of $8000 \mathrm{ml}$ solution was collected and concentrated to obtain the $2^{\text {nd }}$ fraction (referred to as "NaCl-1"). A total of $4500 \mathrm{ml}$ of $100 \mathrm{mM} \mathrm{NaCl} / 50 \mathrm{mM}$ Tris- $\mathrm{HCl}$ buffer was collected for the next elution, followed by concentration to obtain fraction NaCl-2. A $4000 \mathrm{ml}$ of $1 \mathrm{M}$ $\mathrm{NaCl} / 50 \mathrm{mM}$ Tris- $\mathrm{HCl}$ buffer was collected for the last elution using to obtain fraction $\mathrm{NaCl}-3$. The whole elution process for obtaining fractionations of urine protein was carried out in a $4^{\circ} \mathrm{C}$ cold chamber to maintain the stability of proteins.

\section{Protein precipitation by trichloroacetic acid/acetone}

The urine protein mixture in the supernatant was precipitated out overnight at $-20^{\circ} \mathrm{C}$ by triple the volume of 
10\% TCA/Acetone solution containing $20 \mathrm{mM} \mathrm{DTT}$ [3]. After centrifugation at $8000 \mathrm{rpm}$ for $30 \mathrm{~min}$ at $4{ }^{\circ} \mathrm{C}$, the supernatant was discarded. The pellet was rinsed three times in cold acetone containing $20 \mathrm{mM}$ DTT and air-dried, and subsequently resuspended overnight at $4^{\circ} \mathrm{C}$ in a rehydration buffer purchased from Bio-Rad (6 M urea, $2 \mathrm{M}$ thiourea, 0.5\% CHAPS, 0.5\% IPG buffer, $20 \mathrm{mM}$ DTT, 0.002\% bromophenol blue). The protein contents were determined using a 2-D Quant Kit (GE Healthcare).

\section{Two-dimensional gel electrophoresis}

The first dimension electrophoresis (isoelectric focusing) was performed on a Bio-Rad PROTEAN IEF Cell at $20^{\circ} \mathrm{C}$ with a current limit of 50 A per strip. A sample was dissolved in rehydration buffer (as described above) and applied on a IPG strip in a strip holder. Every 11-cm pI 4-7 IPG strip (Immobiline DryStrip) was rehydrated at $50 \mathrm{~V}$ for $12 \mathrm{~h}$, then focused according to the preset program $(200 \mathrm{~V}(1.5 \mathrm{~h}), 500 \mathrm{~V}(1 \mathrm{~h}), 1,000 \mathrm{~V}$ $(1 \mathrm{~h}), 4,000 \mathrm{~V}(1 \mathrm{~h}), 8,000 \mathrm{~V}(2 \mathrm{~h}))$ until the total Vh reached 19,960 . On the other hand, every $11-\mathrm{cm}$ pI 3-10NL IPG strip was rehydrated at $30 \mathrm{~V}$ for $12 \mathrm{~h}$, then focused according to the preset program $(200 \mathrm{~V}(1.5 \mathrm{~h})$, $500 \mathrm{~V}(1 \mathrm{~h}), 1,000 \mathrm{~V}(1 \mathrm{~h}), 4,000 \mathrm{~V}(1 \mathrm{~h}), 8,000 \mathrm{~V}(3 \mathrm{~h})$, until the total Vh reached 27,960.

After isoelectric focusing, the strip was removed and equilibrated for $10 \mathrm{~min}$ in a $5 \mathrm{ml}$ buffer $(50 \mathrm{mM}$ Tris$\mathrm{HCl}, \mathrm{pH} 8.8,6 \mathrm{M}$ urea, 30\% glycerol, 2\% SDS, 0.01\% bromophenol blue) containing $1 \%(\mathrm{w} / \mathrm{v})$ DTT, then transferred to another $5 \mathrm{ml}$ equilibration buffer containing $2.5 \%(\mathrm{w} / \mathrm{v})$ iodoacetamide for an additional $10 \mathrm{~min}$. The equilibrated strip was placed on the top of a SDSPAGE gel (12.5\%), sealed with $0.5 \%$ agarose, followed by the running of a second dimension electrophoresis at $150 \mathrm{~V}$ for $6.5 \mathrm{~h}$. The electrophoretic unit used for the second dimension electrophoresis was an SE 600 Ruby (Hoeffer).

\section{Protein spot identification by LC-MS/MS In-gel Digestion}

A $1 \mathrm{~mm} \times 1 \mathrm{~mm}$ piece of protein at the spot of interest was excised and placed into a microcentrifuge tube. A $100 \mu$ lof $50 \mathrm{mM}$ DTT in $25 \mathrm{mM}$ ammonium bicarbonate $(\mathrm{pH} 8.5)$ was added to the tube which was shaken for $1 \mathrm{~h}$ at $37^{\circ} \mathrm{C}$. After removing excess DTT in the supernatant, $100 \mu \mathrm{l}$ of $100 \mathrm{mM}$ Iodoacetamide (IAA) in $25 \mathrm{mM}$ ammonium bicarbonate $(\mathrm{pH} 8.5)$ was added to the tube which was shaken for $30 \mathrm{~min}$ at $\mathrm{RT}$ in the dark. The excess IAA in the supernatant was removed. Next, $100 \mu \mathrm{l}$ of $50 \%$ acetonitrile in $25 \mathrm{mM}$ ammonium bicarbonate buffer ( $\mathrm{pH} 8.5$ ) was added, and the gel piece was soaked for 15 minutes followed by a complete removal of the buffer. The destaining process was carried out two or more times depending on the intensity of the dye. The gel piece was soaked in a $100 \mu \mathrm{l}$ of $100 \%$ acetonitrile for 5 minutes and dried by SpeedVac to remove the remaining acetonitrile. After drying, $0.1 \mu \mathrm{g}$ of trypsin in $10 \mu \mathrm{l} 25 \mathrm{mM}$ ammonium bicarbonate $(\mathrm{pH} 8.5)$ was added to the gel piece. One hour later, another $100 \mu \mathrm{l} 25 \mathrm{mM}$ ammonium bicarbonate was added and digestion was run for $16 \mathrm{~h}$ at $37^{\circ} \mathrm{C}$. Following, $50 \mu \mathrm{l}$ of $5 \%$ TFA in $50 \%$ acetonitrile was added to quench the trypsin digestion. The solution was sonicated for 10 second to release the tryptic peptides from the gel. The peptide solution was concentrated for the following LC-MS/MS analysis.

\section{LC-MS/MS analysis}

The above peptide mixture was subjected to a CapLC system (Waters, Milford, MA,) using a capillary column (75 um i.d., $10 \mathrm{~cm}$ in length, C SUN, Taiwan) with a linear gradient from $5 \%$ to $50 \%$ acetonitrile containing $0.1 \%$ formic acid for a total duration of $46 \mathrm{~min}$ utes. The separated peptides were analyzed online under positive survey scan mode on a nano-ESI QTOF (Micromass, UK) instrument. The scan range was from m/z 400 to 1600 for MS and m/z 50 to 2000 for MS/MS. The raw data was processed into a text file format of PKL with MassLynx 4.0 (subtract 30\%, smooth 3/2 Savitzky Golay and center three channels $80 \%$ centroid).

\section{Database search}

For purposes of protein identification, the PKL files generated from MS/MS spectra were uploaded to the MASCOT search engine v2.2 (Matrix Science, UK) (http:// www.matrixscience.com). The parameters selected for searching the database were as follows: a) protein database was set to NCBInr, b) taxonomy was set as human, c) a single trypsin missed cleavage was allowed, d) the mass tolerance was set to be $0.3 \mathrm{Da}$ for both precursor and product ions, e) carbamidomethyl (C) was chosen as a fixed modification, $\mathrm{f}$ ) deamidated (NQ), oxidation $(\mathrm{M})$, Carbamidomethyl (K) and Carbamidomethyl (N-term) were chosen for variable modifications, and finally, g) the data was formatted into Micromass (.pkl) and ESI-QUAD-TOF was the chosen instrument. Proteins with scores above the significance threshold ( $\mathrm{p}<$ $0.05)$ were identified. All significant hits have at least two matched peptides.

\section{Western blot analysis}

Either 1-D or 2-D gel was transferred to a PVDF membrane (Millipore) for $1.5 \mathrm{~h}$ at $400 \mathrm{~mA}$ using Transphor TE 62 (Hoeffer). The membrane was then blocked overnight by a blocking solution $(50 \mathrm{mM}$ Tris- $\mathrm{HCl}, \mathrm{pH} 8.0$, $0.25 \%$ gelatin, $150 \mathrm{mM} \mathrm{NaCl}, 5 \mathrm{mM}$ EDTA, $0.05 \%$ Tween 20). An antibody with appropriate dilution was added to the membrane and incubated at room 
temperature for $2 \mathrm{~h}$. Rabbit anti-ZAG, anti-CRT, and anti-RBP4 polyclonal antibodies were purchased from ProteinTech Group, USA. Rabbit anti-HP polyclonal antibody was purchased from Rockland, USA. Mouse anti-b-actin monoclonal antibody was purchased from Sigma-Aldrich, USA. Mouse anti-Immunoglobulin monoclonal antibody was purchased from GenWay Biotech, USA. The membrane was washed three times in PBST (10 mM NaH${ }_{2} \mathrm{PO}_{4}, 130 \mathrm{mM} \mathrm{NaCl}, 0.05 \%$ Tween 20 ), then probed with the second Ab (goat anti-mouse IgG and horseradish peroxidase conjugate, 1:10,000 in blocking solution) for $1 \mathrm{~h}$. After it was washed three times with PBST, the enzyme activity on the blot was visualized through chemiluminesence by adding ECL Western Blotting Reagents (Pierce).

\section{Results and Discussion}

\section{2-DE maps of urine proteome}

A $2000 \mathrm{ml}$ urine sample was collected from 20 healthy people. In order to eliminate individual differences, the samples were pooled together and concentrated by Stirred Ultrafiltration Cell 8400. The proteins were precipitated by $10 \%$ TCA/Acetone after dialysis.

An equal amount of $50 \mu \mathrm{g}$ per gel was resolved in 2-DE using IPG strips (pI 4-7 and pI 3-10NL). The protein spots were visualized with silver stain and were excised for subsequent in-gel digestion and identification by LC-MS/MS. A total of 350 protein spots were detected in Figure $1 \mathrm{~A}$ and a total of 220 spots were detected in Figure $1 \mathrm{~B}$ by comparative analysis using PDQuest 2-D software (version 7.1.1). A direct 2-DE analysis of a complex protein sample can encounter resolution problems, and not all proteins can be detected on a 2-DE map. The difference in resolution could explain why more protein spots were detected in Figure 1A than in Figure 1B. The protein identification was carried out by LC-MS/MS. The spots N33 N36, identified in Figures $1 \mathrm{~A}$ and $1 \mathrm{~B}$, were immunoglobulin heavy and light chain proteins which were also listed in Table 1. Mouse anti-human immunoglobulin monoclonal antibody was also used for 2-D immunoreactivity analysis to confirm the data as shown in Figures $1 \mathrm{C}$ and 1D. The results clearly indicate that immunoglobulin heavy and light chain proteins are high-abundant in urine, which obscure the presence of the lowabundance proteins. Thus, it is necessary to remove the abundant proteins to enrich the low-abundance proteins. The application of nProtein A Sepharose (GE Healthcare) was widely used for removing immunoglobulin from a protein mixture. An attempt to remove immunoglobulin proteins in urine by nProtein $\mathrm{A}$ Sepharose was not successful (results reported in the additional file 1: Supplemental section and Additional file 2: figure $\mathrm{S} 1$ ).

\section{Fractionation of urine proteome by non-fixed volume stepwise WAX with $\mathrm{NaCl}$ solutions}

Ion exchange chromatography depends on chargecharge interactions between the proteins of a sample and the charges immobilized on the resin. In anion exchange chromatography the binding ions are negatively charged and the immobilized functional groups are positively charged. Once the solutes are bound to the gel, the column is washed in a starting buffer to equilibrate, then the bound molecules are eluted off in a stepwise manner using a salt solution with increasing ionic strength. At low ionic strengths, competition for charged proteins on gel resin is at a low level, therefore they are bound strongly on gel resin. When the ionic strength increases, so does the competition, and in turn, the affinity between proteins and gel resin decreases. The end result is more bound proteins being released from the gel resin. Thongboonkerd et al. used SP Sepharose Fast Flow Bead (a cationic ion exchange chromatography) to enrich the basic proteins in urine such as eosinophil-derived neurotoxin and interferon alpha [20]. This study used stepwise elution anion exchange chromatography for the fractionation of urine proteins and the enrichment of low-abundance proteins. The recovery rates of proteins were between $72.1 \%$ and $74.2 \%$. The non-fixed volume stepwise elution method offers the potential of high resolution in preparative applications. Ideally, the non-fixed volume stepwise elution can eliminate the overlapping distribution of proteins in two neighboring fractions. The 2-DE maps of the four fractions of total urine protein eluted by $\mathrm{NaCl}$ (fraction Unbound, fraction $\mathrm{NaCl}-1$, fraction $\mathrm{NaCl}-2$, and fraction $\mathrm{NaCl}-3$ ) were shown in Figure 2A to 2D.

The protein spots were visualized with silver stain which is a sensitive method for the appearance of protein with a limitation on dynamic range. In practice, the disadvantage for making more protein spots visible is the resulting smear around some spots. Three replicates were done for the 2D electrophoresis of each urine fractions. By comparative analysis using PDQuest 2-D software (version 7.1.1) a total of $40 \pm 3.6$ (average \pm SD) protein spots (range 36-43) were detected in Figure 2A for fraction Unbound, a total of $278 \pm 3.2$ spots (range 274-280) were detected in Figure 2B for fraction $\mathrm{NaCl}$ 1 , a total of $222 \pm 8.3$ spots (range 213-229) were detected in Figure $2 \mathrm{C}$ for fraction $\mathrm{NaCl}-2$, and a total of $68 \pm 5.6$ spots (range 62-73) were detected in Figure 2D for fraction $\mathrm{NaCl}-3$. Comparing with the 2-DE map of total urine protein without pre-fractionation, the number of spots recognized by PDQuest 2-D software was significantly higher. The additional file 1: Supplemental section and Additional file 3: figure S2A-S2D show the corresponding 2-DE maps of the fractions run by $\mathrm{pI}$ 3-10NL. The very different silver staining patterns of the 


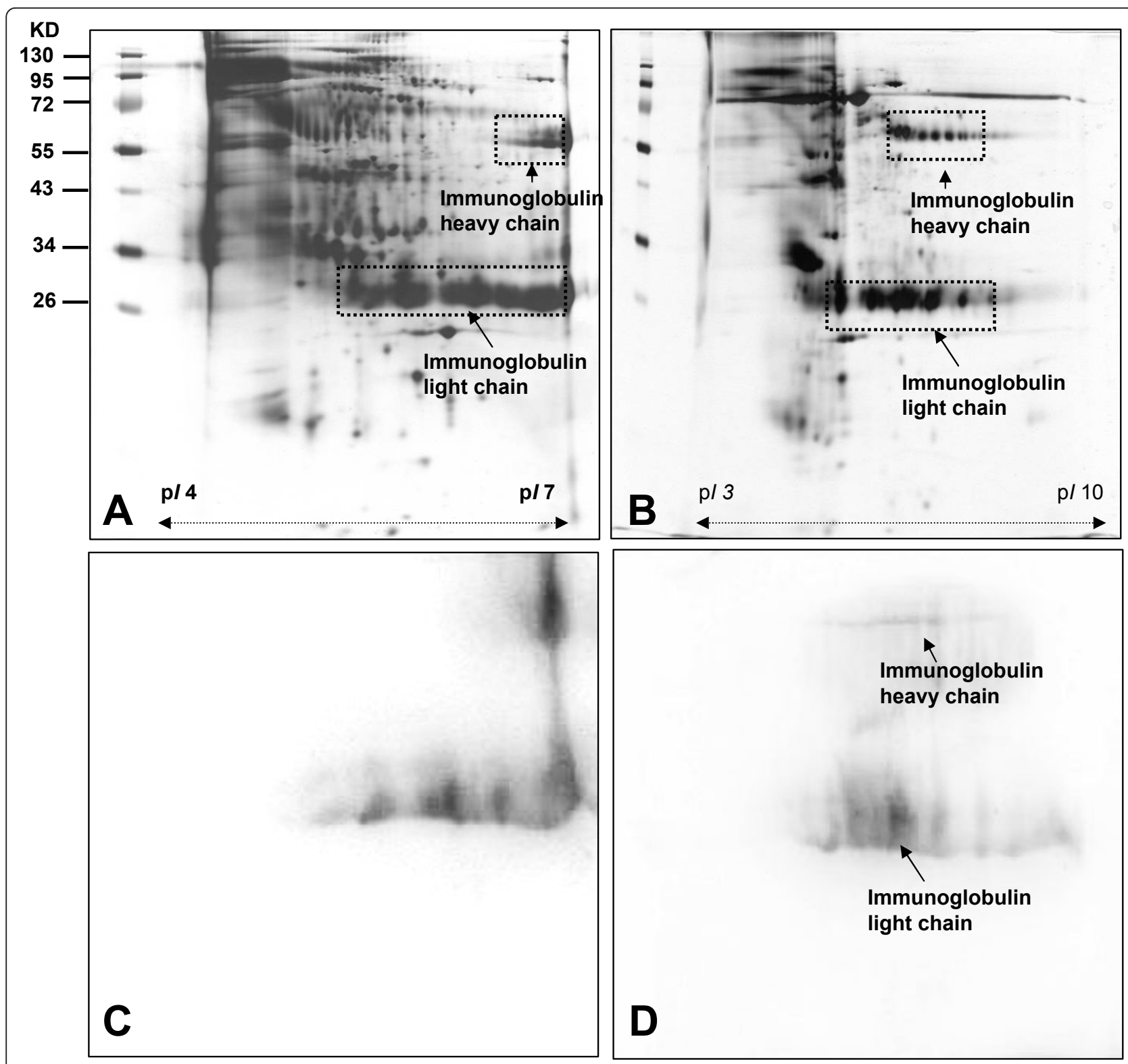

Figure 1 Two-DE maps of urine proteome of healthy people. (A) A total of 350 protein spots were detected at p/ 4-7, and (B) a total of 220 spots were detected at p/ 3-10NL by comparative analysis with PDQuest 2-D software. (C) 2-D western blot analysis immunoglobulin of total urine protein ( $p / 4-7)(D) 2-D$ western blot analysis immunoglobulin of total urine protein ( $p / 3-10 N L)$.

four 2-DE maps indicate that an efficient fractionation of urine proteins was achieved. Most of the high-abundance proteins including immunoglobulin heavy and light chain proteins, appeared in Figure 2A. The lowabundance proteins were enriched in fraction $\mathrm{NaCl}-1$ to fraction $\mathrm{NaCl}-3$ (as shown in Figure $2 \mathrm{~B}$ to $2 \mathrm{D}$ ). The identities of 32 protein spots $(\mathrm{N} 1 \sim \mathrm{N} 32)$ analyzed by LC-MS/MS after excision and in-gel digestion were reported in Table 1 . The major protein spots identified in fraction Unbound were immunoglobulin heavy and light chain and prostaglandin $\mathrm{H} 2 \mathrm{D}$-isomerase. When a mouse monoclonal antibody against human immunoglobulin was incubated in either total urine proteins versus the four fractions, immunoreactivities were present in total urine protein but only in fraction Unbound as shown in Figure 3B. In unison, it has been shown that the above fractionation method is effective in separating immunoglobulin heavy and light chain proteins from other urine proteins.

Some protein spots identified in fraction $\mathrm{NaCl}-1$ and fraction $\mathrm{NaCl}-2$ have several isoforms including, zn-alpha-2-glycoprotein (ZAG), inter-alpha-trypsin inhibitor family heavy chain-related protein (IHRP), retinol binding protein 4 (RBP4), heparan sulfate proteoglycan 
Table 1 Summary of protein spots of healthy urine identified by LC-MS/MS

\begin{tabular}{|c|c|c|c|c|c|c|}
\hline $\begin{array}{c}\text { Spot } \\
\text { number }\end{array}$ & Protein name & NCBI acc.no & $\begin{array}{c}\text { Calculate } \\
\mathrm{Mr} / \mathrm{pl}\end{array}$ & $\begin{array}{l}\text { Peptide } \\
\text { matched }\end{array}$ & $\begin{array}{l}\text { Sequence } \\
\text { covered } \%\end{array}$ & $\begin{array}{c}\text { MASCOT } \\
\text { score }\end{array}$ \\
\hline N1 & Chain G, Gelsolin G4-G6 actin complex & 1H1V_G & $36.3 / 5.0$ & 15 & 56 & 587 \\
\hline N2 & Chain G, Gelsolin G4-G6 actin complex & 1H1V_G & $36.3 / 5.0$ & 11 & 42 & 430 \\
\hline N3 & keratin 10 & XP_001169450 & $58.7 / 5.13$ & 16 & 23 & 541 \\
\hline N4 & Zn-alpha2-glycoprotein & CAA42438 & $34.7 / 5.71$ & 10 & 20 & 249 \\
\hline N5 & Zn-alpha2-glycoprotein & CAA42438 & $34.7 / 5.71$ & 11 & 41 & 357 \\
\hline N6 & Zn-alpha2-glycoprotein & CAA42438 & $34.7 / 5.71$ & 11 & 30 & 317 \\
\hline N7 & Zn-alpha2-glycoprotein & CAA42438 & $34.7 / 5.71$ & 19 & 34 & 458 \\
\hline N8 & mannose-binding lectin 2 & NP_006807 & $40.2 / 6.46$ & 8 & 9 & 187 \\
\hline N9 & mannose-binding lectin 2 & NP_006807 & $40.2 / 6.46$ & 10 & 25 & 251 \\
\hline N10 & mannose-binding lectin 2 & NP_006807 & $40.2 / 6.46$ & 13 & 23 & 262 \\
\hline N11 & $\begin{array}{l}\text { inter-alpha-trypsin inhibitor family heavy chain- } \\
\text { related protein }\end{array}$ & BAA07602 & 103/6.51 & 10 & 9 & 453 \\
\hline N12 & $\begin{array}{l}\text { inter-alpha-trypsin inhibitor family heavy chain- } \\
\text { related protein }\end{array}$ & BAA07602 & 103/6.51 & 18 & 11 & 456 \\
\hline N13 & alpha-1-microglobulin/bikunin precursor & NP_001624 & $38.9 / 5.95$ & 6 & 7 & 89 \\
\hline N14 & alpha-1-microglobulin/bikunin precursor & NP_001624 & $38.9 / 5.95$ & 11 & 28 & 308 \\
\hline N15 & complex-forming glycoprotein $\mathrm{HC}$ & 0801163A & $20.4 / 5.84$ & 24 & 50 & 348 \\
\hline N16 & $\begin{array}{l}\text { inter-alpha-trypsin inhibitor family heavy chain- } \\
\text { related protein }\end{array}$ & BAA07602 & 103/6.51 & 7 & 8 & 261 \\
\hline N17 & $\begin{array}{l}\text { inter-alpha-trypsin inhibitor family heavy chain- } \\
\text { related protein }\end{array}$ & BAA07602 & 103/6.51 & 12 & 11 & 286 \\
\hline N18 & $\begin{array}{l}\text { inter-alpha-trypsin inhibitor family heavy chain- } \\
\text { related protein }\end{array}$ & BAA07602 & 103/6.51 & 8 & 7 & 296 \\
\hline N19 & prostaglandin $\mathrm{H} 2 \mathrm{D}$-isomerase & NP_000945 & 21.0/7.66 & 10 & 28 & 239 \\
\hline $\mathrm{N} 20$ & heparan sulfate proteoglycan 2 & XP_001099299 & $468 / 6.06$ & 1 & 17 & 260 \\
\hline N21 & heparan sulfate proteoglycan 2 & XP_001099299 & $468 / 6.06$ & 1 & 22 & 304 \\
\hline N22 & mannan-binding lectin-associated serine protease-2 & CAA67050 & $75.6 / 5.42$ & 8 & 25 & 238 \\
\hline N23 & mannan-binding lectin-associated serine protease-2 & CAA67050 & $75.6 / 5.42$ & 1 & 2 & 82 \\
\hline N24 & retinol binding protein 4 & $1 \mathrm{RBP}$ & 20.9/5.27 & 14 & 20 & 171 \\
\hline N25 & retinol binding protein 4 & 1RBP & 20.9/5.27 & 15 & 33 & 560 \\
\hline N26 & immunoglobulin kappa light chain VLJ region & BAC01709 & 29.0/5.46 & 22 & 31 & 741 \\
\hline N27 & immunoglobulin kappa light chain VLJ region & BAC01762 & $28.4 / 7.53$ & 2 & 9 & 84 \\
\hline N28 & immunoglobulin heavy chain & CAC10254 & $39.7 / 8.3$ & 11 & 17 & 240 \\
\hline N29 & immunoglobulin heavy chain & CAC10254 & $39.7 / 8.3$ & 17 & 16 & 303 \\
\hline N30 & vitelline membrane outer layer 1 isoform 1 & NP_872372 & $21.5 / 4.9$ & 3 & 24 & 99 \\
\hline N31 & beta globin chain & AAA35952 & $18.9 / 6.28$ & 2 & 13 & 99 \\
\hline N32 & beta globin chain & ACF16774 & $11.4 / 6.9$ & 5 & 48 & 192 \\
\hline
\end{tabular}

(HSPG), mannan-binding lectin-associated serine protease-2 (MASP-2), mannose binding lectin (MBL) and alpha-1-microglobulin/bikunin precursor (Figure 2B and $2 \mathrm{C})$. In order to confirm the proteomic results, western blot analysis of some urine proteins was carried out. When a mouse monoclonal antibody of anti-human ZAG was incubated with total urine protein and the four fractions, immunoreactivities were identified in total urine protein but only in one of 4 fractions (fraction $\mathrm{NaCl}-1$ ) as shown in Figure 3C. When a mouse antibody anti-human RBP4 was used, a similar phenomena was obtained as shown in Figure 3D. The results indicated that the stepwise elution DEAE-Sephacel anion exchange chromatography was effective in removing abundant proteins from total urine protein for the enrichment of low-abundance proteins.

Due to the presence of isoforms, only 15 proteins were identified from the 32 protein spots. It was likely that many of the proteins went through protein modification such as glycosylation or phosphorylation, presenting continuous spots on the 2-DE map. Each of the five proteins including ZAG, IHRP, RBP4, MASP-2, and HSPG with different $\mathrm{p} I$, molecular weights, or isoforms appeared on the 2-DE map as more than one spot. ZAG (spot N4 N7) is a glycoprotein with a molecular mass $\sim 41 \mathrm{kDa}$. It appears in most body fluid, such as sweat, 


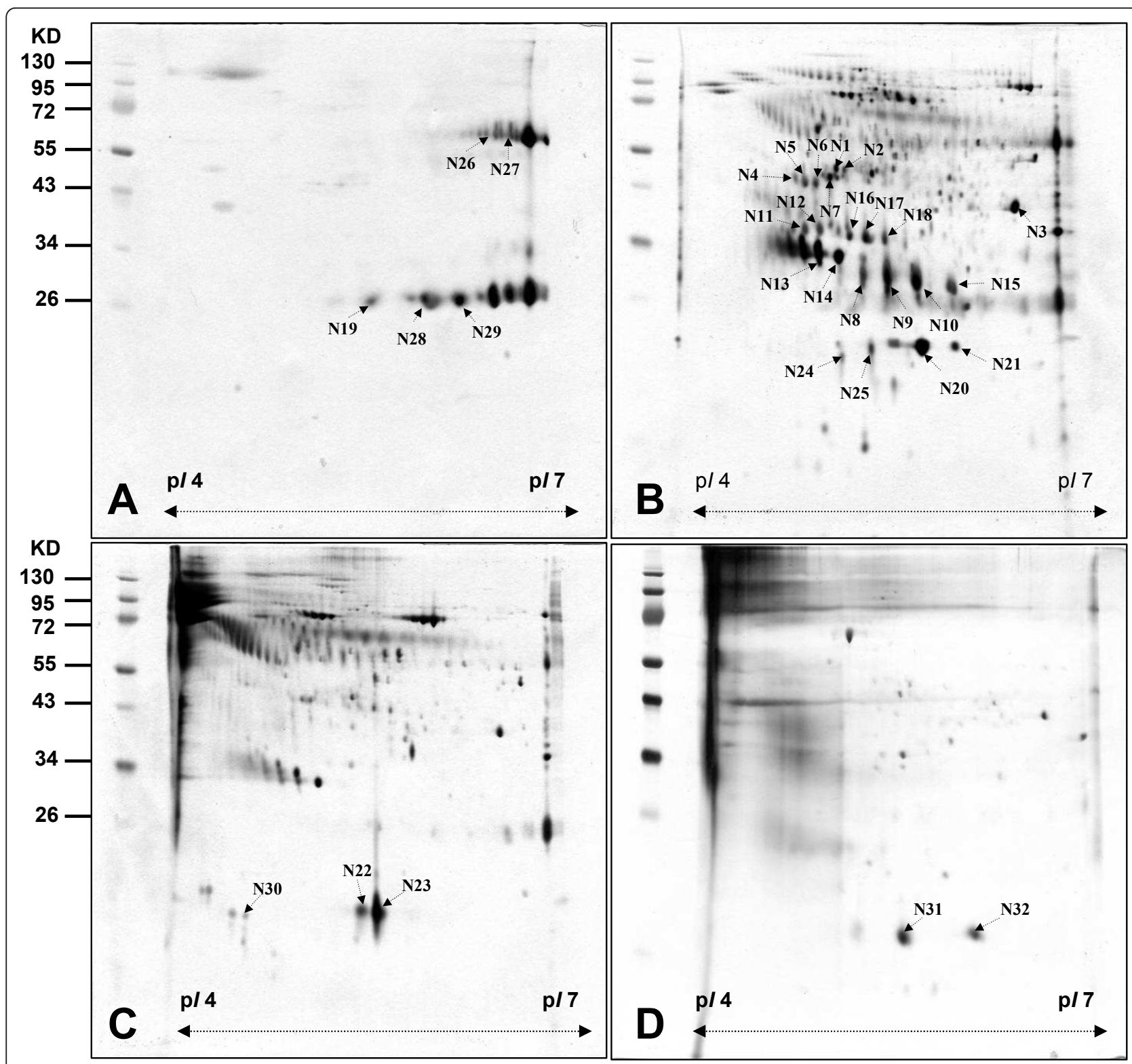

Figure 2 2-DE maps of fractions of urine proteome of healthy people obtained by non-fixed volume stepwise elution DEAE-Sephacel anion exchange chromatography. ( $\mathrm{p} / 4-7$ ) (A) unbound Proteins in fraction (B) Proteins in fraction $\mathrm{NaCl}-1$ obtained by elution with $50 \mathrm{mM}$ $\mathrm{NaCl}$. (C) Proteins in fraction NaCl-2 obtained by elution with $100 \mathrm{mM} \mathrm{NaCl}$. (D) Proteins in fraction $\mathrm{NaCl}-3$ obtained by elution with $1 \mathrm{M} \mathrm{NaCl}$.

urine, blood, and cerebrospinal fluid. RBP4 (spot N24,25) is a carrier protein that transports retinol from the liver to the peripheral tissues and has been reported as a potential biomarker for glomerular disease [22]. As most reports of RBP4 in urine are related to disease, the significance of its existence in the urine of a healthy person is unknown. IHRP (spots N12, N16 N18) is identified as an acute phase protein in animals that may function as an anti-inflammatory protein [23]. HSPG (spot N20, 21) have a potential role in glomerular filtration. Further, MBL (spot N8 N10), a collagen-like serum protein, is a key component of innate immunity, which binds to carbohydrates on pathogens and mediates lectin-dependent activation of the complement pathway [24]. MASP2 (spot N22, 23) is an enzyme of the innate immune system, which is activated when one of these proteins recognizes microorganisms and subsequently cleaves complement factors $\mathrm{C} 4$ and $\mathrm{C} 2$, and initiates the activation of the complement system [25]. All five proteins discussed above have direct links with immune response and inflammation, and have all been previously identified by Adachi et al. who used one-dimensional sodium dodecyl sulfate polyacrylamide gel and reverse phase high-performance liquid chromatography [26]. Although a large 


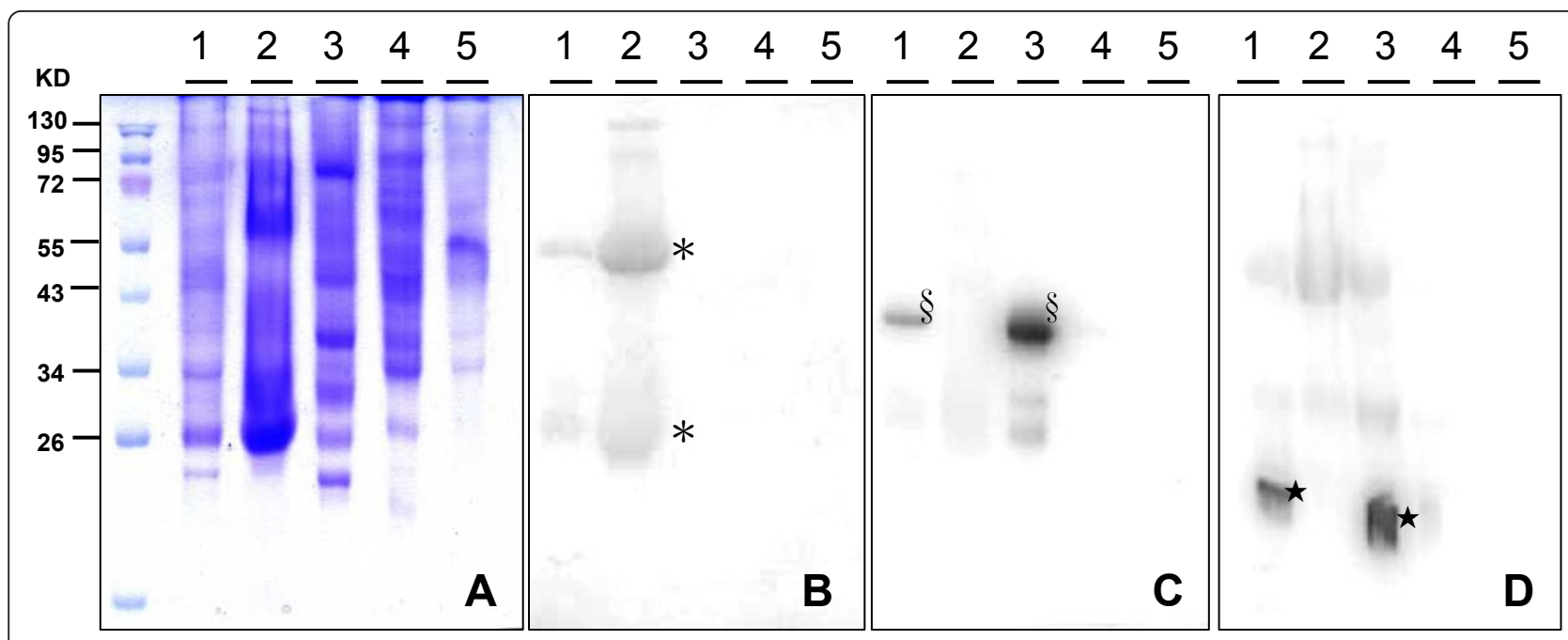

Figure 3 Western blot analysis of immunoglobulins, zinc-alpha-2-glycoprotein and retinol-binding protein 4 in urine proteome and fractions of urine proteome of healthy people. (A) CBR staining patterns of total urine protein (1), fraction Unbound (2), fraction NaCl-1 (3), fraction $\mathrm{NaCl}-2$ (4) and fraction NaCl-3 (5). (B) Immunoreactivity to mouse anti-human immunoglobulin antibody. Two bands, indicating immunoglobulin heavy and light chain, appeared only in 2 (fraction Unbound) and total urine protein. (C) Immunoreactivity to mouse antihuman zinc-alpha-2-glycoprotein antibody. The band appeared only in 3 (fraction NaCl-1) and total urine protein. (D) Immunoreactivity to mouse anti-human retinol-binding protein 4 antibody. The band appeared only in 3 (fraction $\mathrm{NaCl}-1$ ) and total urine protein.

number of urine proteins were identified in this prior study $(\mathrm{n}=1543)$, mass spectrometry analysis could not identify protein isoforms and possible post-translation modification. The strength of 2-DE analysis comes from both the qualitative and quantitative protein information revealed on the 2-DE maps. It is anticipated that potential disease biomarkers could be identified by detecting the qualitative and quantitative difference between the 2DE maps of fractions of urine protein of patients and normal people using LC-MS/MS and western blotting analysis. In this study, DEAE-Sephacel was used as the gel resin in stepwise elution anion exchange chromatography with clean separation to fractionate total urine protein and enrich low-abundance proteins with encouraging results.

\section{Conclusions}

The results demonstrated that non-fixed volume, stepwise elution, weak anion exchange chromatography with clean separation using DEAE-Sephacel as gel resin was an effective approach for the fractionation of total urine protein and the enrichment of low-abundance proteins. Four fractions of total urine protein were obtained by stepwise elution of the column, first without $\mathrm{NaCl}$ until no protein was detected in the eluting solution, followed by $50 \mathrm{mM} \mathrm{NaCl}$ solution until no protein was detected in the eluting solution. The next two fractions were obtained by eluting with $100 \mathrm{mM} \mathrm{NaCl}$ solution and $1 \mathrm{M} \mathrm{NaCl}$ solution, respectively. The 2-DE maps of the four fractions have been established. Identification of 32 protein spots by LC-MS/MS after excision and in-gel digestion have been carried out. Most of the immunoglobulin heavy and light chain proteins, which are abundant proteins in urine, only appeared in one of the fractions. Western blot analysis of immunoglobulin, ZAP, and RBP4 have been carried out to confirm the proteomic results. Identification of more protein spots are being carried out to better understand the whole scope of the urine proteins. This fractionation method is robust for the removal of high-abundance proteins, and can provide distinct fractionations for a more comprehensive profiling of protein expression. Although a large number of urine proteins could be identified by using the LC-MS/MS method alone, the MS analysis could not identify protein isoforms and possible post-translation modification. Overall, the non-fixed volume WAX fractionation coupled with the downstream 2-DE analysis can provide a more comprehensive display of differential proteins and is potentially useful for the identification and quantitation of protein isoforms and the detection of low-abundant proteins. Targeted MS screening approaches with sensitive detection and accurate quantification, such as multiple reaction monitoring (MRM), will be carried out to evaluate the differential proteins for the identification of potential disease biomarkers.

The solutions of two other salts, $\mathrm{Na}_{2} \mathrm{SO}_{4}$ and $\mathrm{MgCl}_{2}$, were also used for the elution. The method and result were reported in the additional file 1: Supplemental section and Additional file 4: figure S3. The 2-DE maps of 
the fractions obtained by elution with different salt solution possessing the same ionic strengths showed significantly different stain patterns. The results demonstrated the potential applications of this fractionation method using different salts for achieving diversified fractionation of human urine and enrichment of low-abundance proteins. It is believed that this method could be applied to the enrichment of low-abundance proteins in other body fluids such as serum, tear, saliva, cerebrospinal fluid, synovial fluid, cells, and tissues.

$\mathrm{Wu}$ et al. had reported a novel method for establishing a monoclonal antibody bank [27]. Applying complex antigens for mouse immunization and using 1-DE and 2-DE for immunoreactivity to identify monoclonal antibodies, a large number of pure monoclonal antibodies have been isolated. In this study, the developed stepwise elution DEAE-Sephacel anion exchange chromatography was effective in obtaining clean fractionations of urine proteins and enrichment of low-abundance proteins. A combination of both methods could offer a potentially promising way to establish a complete monoclonal antibody bank of urine proteome. Immunization with each fraction of urine proteins will be carried out to generate antibodies which will be separated into many pure monoclonal antibodies utilizing the method of Wu et al. The establishment of monoclonal antibody bank of urine proteome and the subsequent preparation of antibody chips of disease biomarkers could be used for simple and expedited disease screening.

\section{Additional material}

Additional file 1: Supplemental Section. Three additional experiments: 1. Separation of immunoglobulin in urine proteome by $n$ Protein $A$ Sepharose, 2. 2-DE maps for pl 3-10, 3. Fractionation of urine proteome by non-fixed volume stepwise WAX with $\mathrm{Na}_{2} \mathrm{SO}_{4}$, and $\mathrm{MgCl}_{2}$ solutions.

Additional file 2: Figure S1. Separation of immunoglobulin from urine of healthy people by nProtein A Sepharose. (A) Urine proteins not adsorbed to the gel resin. (B) Urine proteins adsorbed to the gel resin. The presence of immunoglobulin heavy and light chain proteins on both maps indicates that only partial removal of immunoglobulins was achieved by nProtein A Sepharose.

Additional file 3: Figure S2. 2-DE maps of fractions of urine proteome of healthy people obtained by non-fixed volume stepwise elution DEAESephacel anion exchange chromatography. (p/3-10NL) (A) Unbound proteins in fraction (B) Proteins in fraction $\mathrm{NaCl}-1$ obtained by elution with $50 \mathrm{mM} \mathrm{NaCl}$. (C) Proteins in fraction $\mathrm{NaCl}-2$ obtained by elution with $100 \mathrm{mM} \mathrm{NaCl}$. (D) Proteins in fraction $\mathrm{NaCl}-3$ obtained by elution with $1 \mathrm{M} \mathrm{NaCl}$

Additional file 4: Figure S3. Comparison of 2-DE maps of fractions of urine proteome of healthy people obtained by non-fixed volume stepwise elution DEAE-Sephacel anion exchange chromatography. ( $p / 3$ $10 \mathrm{NL}$ ) (A) Proteins in fraction $\mathrm{NaCl}-1$ obtained by elution with 50

List of Abbreviations

2-DE: Two-dimensional gel electrophoresis; CRT: Calreticulin; Hp: Haptoglobin; HSPG: Heparan sulfate proteoglycan; IHRP: Inter-alpha-trypsin inhibitor family heavy chain-related protein; MASP-2: Mannan-binding lectinassociated serine protease-2; RBP4: Retinol-binding protein 4; WAX: Weak anion exchange; ZAG: Zinc-alpha-2-glycoprotein.

\section{Acknowledgements}

This study was supported by the Buddhist Dalin Tzu Chi General Hospital Research Fund (Project No. DTCRD96(2)-14 and Project No. DTCRD97-03) and Center of Excellence for Environmental Medicine, Kaohsiung Medical University.

\section{Author details}

${ }^{1}$ Graduate Institute of Medicine, College of Medicine, Kaohsiung Medical University, Kaohsiung, Taiwan. ${ }^{2}$ Department of Urology, Buddhist Da Lin Tzu Chi General Hospital, Chiayi, Taiwan. ${ }^{3}$ Department of Beauty Science, Meiho University, Pingtung, Taiwan. ${ }^{4}$ Graduate Institute of Biotechnology, National Pingtung University of Science and Technology, Pingtung, Taiwan. ${ }^{5}$ Department of Food Science and Nutrition, Meiho University, Pingtung, Taiwan. ${ }^{6}$ Department of Biotechnology, Kaohsiung Medical University, Kaohsiung, Taiwan. ${ }^{7}$ Department of Urology, Center of Excellence for Environmental Medicine, Kaohsiung Medical University, Kaohsiung, Taiwan. ${ }^{8}$ Center of Excellence for Environmental Medicine, Kaohsiung Medical University, Kaohsiung, Taiwan.

\section{Authors' contributions}

$\mathrm{CL}, \mathrm{YW}$, and $\mathrm{CC}$ collected the urine samples, performed the proteomic experiments, and wrote the manuscript. $J \mathrm{H}, \mathrm{JC}$, and JYC performed the proteomic experiments. $\mathrm{CL}, \mathrm{YW}, \mathrm{CH}$, and $\mathrm{YK}$ designed the experiments and oversaw the IRB approval procedure. YK supervised the work, provided suggestions for solving problems, and revised the manuscript. All authors have read and approved the manuscript.

\section{Competing interests}

The authors declare that they have no competing interests.

Received: 5 December 2010 Accepted: 8 April 2011

Published: 8 April 2011

\section{References}

1. Pang J, Ginanni N, Dongre A, Hefta S, Opitek G: Biomarker discovery in urine by proteomics. J Proteome Res 2002, 1:161-169.

2. Lafitte D, Dussol B, Andersen S, Vazi A, Dupuy P, Jensen O, Berland $Y$, Verdier J: Optimized preparation of urine samples for two-dimensional electrophoresis and initial application to patient samples. Clin Biochem 2002, 35:581-589.

3. Kiernan U, Tubbs K, Nedelkov D, Niederkofler E, McConnell E, Nelson R: Comparative urine protein phenotyping using mass spectrometric immunoassay. J Proteome Res 2003, 2:191-197.

4. Rehman I, Azzouzi A, Catto J, Allen S, Cross S, Feeley K, Meuth M, Hamdy F: Proteomic analysis of voided urine after prostatic massage from patients with prostate cancer: a pilot study. Urology 2004, 64:1238-1243.

5. Marshall T, Williams K: Clinical analysis of human urinary proteins using high-resolution electrophoretic methods. Electrophoresis 1998, 19:1752-1770.

6. Vlahou A, Schellhammer P, Mendrinos S, Patel K, Kondylis F, Gong L Nasim S, Wright GJ Jr: Development of a novel proteomic approach for the detection of transitional cell carcinoma of the bladder in urine. Am J Pathol 2001, 158:1491-1502.

7. Lin C, Tsui K, Yu C, Yeh C, Chang P, Yung B: Searching cell-secreted proteomes for potential urinary bladder tumor markers. Proteomics 2006, 6:4381-4389.

8. Tantipaiboonwong P, Sinchaikul S, Sriyam S, Phutrakul S, Chen S: Different techniques for urinary protein analysis of normal and lung cancer patients. Proteomics 2005, 5:1140-1149.

9. Ye B, Skates S, Mok S, Horick N, Rosenberg H, Vitonis A, Edwards D, Sluss P, Han W, Berkowitz R, Cramer D: Proteomic-based discovery and characterization of glycosylated eosinophil-derived neurotoxin and $\mathrm{COOH}$-terminal osteopontin fragments for ovarian cancer in urine. Clin Cancer Res 2006, 12:323-327.

10. M'Koma A, Blum D, Norris J, Koyama T, Billheimer D, Motley S, Ghiassi M, Ferdowsi N, Bhowmick I, Chang S, et al: Detection of pre-neoplastic and neoplastic prostate disease by MADI profiling of urine. Biochem Biophys Res Commun 2007, 353:829-834. 
11. Ngai $H$, Sit W, Jiang $P, X u R$, Wan J, Thongboonkerd V: Serial changes in urinary proteome profile of membranous nephropathy: implications for pathophysiology and biomarker discovery. J Proteome Res 2006, 5:3038-3047.

12. Sharma K, Lee $S$, Han $S$, Lee $S$, Francos B, McCue P, Wassell R, Shaw M, RamachandraRao S: Two-dimensional fluorescence difference gel electrophoresis analysis of the urine proteome in human diabetic nephropathy. Proteomics 2005, 5:2648-2655.

13. Aviles-Santa L, Alpern R, Raskin P: Reversible acute renal failure and nephritic syndrome in a Type I diabetic patient. J Diabetes Complication 2002, 16:249-254.

14. Cutler P, Bell D, Birrell H, Connelly J, Connor S, Holmes E, Mitchell B, Monte S, Neville B, Pickford R, et al: An integrated proteomic approach to studying glomerular nephrotoxicity. Electrophoresis 1999, 20:3647-3658.

15. Oh J, Pyo JH, Jo E, Hwang S, Kang S, Jung J, Park E, Kim S, Choi J, Lim J: Establishment of a near-standard two-dimensional human urine proteomic map. Proteomics 2004, 4:3485-3497.

16. Thongboonkerd $V$, Malasit P: Renal and urinary proteomics: current applications and challenges. Proteomics 2005, 5:1033-1042.

17. Pieper R, Gatlin CL, McGrath AM, Makusky AJ, Mondal M, Seonarain M, Field E, Schatz CR, Estock MA, Ahmed N, et al: Characterization of the human urinary proteome: a method for high-resolution display of urinary proteins on two-dimensional electrophoresis gels with a yield of nearly 1400 distinct protein spots. Proteomics 2004, 4:1159-1174.

18. Castagna A, Cecconi D, Sennels L, Rappsilber J, Guerrier L, Fortis F, Boschetti E, Lomas L, Righetti PG: Exploring the hidden human urinary proteome via ligand library beads. J Proteome Res 2005, 4:1917-1930.

19. Zerefos P, Vougas K, Dimitraki P, Kossida S, Petrolekas A, Stravodimos K, Giannopoulos A, Fountoulakis M, Vlahou A: Characterization of the human urine proteome by preparative electrophoresis in combination with 2DE. Proteomics 2006, 6:4346-4355.

20. Thongboonkerd V, Semangoen T, Chutipongtanate S: Enrichment of the basic/cationic urinary proteome using ion exchange chromatography and batch adsorption. J Proteome Res 2007, 6:1209-1214.

21. Kushnir MM, Mrozinski P, Rockwood AL, Crockett DK: A depletion strategy for improved detection of human proteins from urine. J Biomol Tech 2009, 20:101-108.

22. Varghese S, Powell T, Budisavljevic M, Oates J, Raymond J, Almeida J, Arthur J: Urine biomarkers predict the cause of glomerular disease. J Am Soc Nephrol 2007, 18:913-922.

23. Choi-Miura N: Novel human plasma proteins, IHRP (acute phase protein) and PHBP (serine protease), which bind to glycosaminoglycans. Curr Med Chem Cardiovasc Hematol Agents 2004, 2:239-248.

24. Thiel S, Kolev M, Degn S, Steffensen R, Hansen A, Ruseva M, Jensenius J: Polymorphisms in mannan-binding lectin (MBL)-associated serine protease 2 affect stability, binding to MBL, and enzymatic activity. J Immunol 2009, 182:2939-2947.

25. Skjoedt MO, Hummelshoj T, Palarasah Y, Honore C, Koch C, Skjodt K, Garred P: A novel mannose-binding lectin/ficolin-associated protein is highly expressed in heart and skeletal muscle tissues and inhibits complement activation. J Biol Chem 2010, 285:8234-8243.

26. Adachi J, Kumar C, Zhang Y, Olsen JV, Mann M: The human urinary proteome contains more than 1500 proteins, including a large proportion of membrane proteins. Genome Biology 2006, 7:R80.

27. Wu Y, Chen H, Wu T, Wu J, Chu R, Juang R: Preparation of monoclonal antibody bank against whole water-soluble proteins from rapid-growing bamboo shoots. Proteomics 2006, 6:5898-5902.

doi:10.1186/1477-5956-9-17

Cite this article as: Lu et al:: Identification of low-abundance proteins via fractionation of the urine proteome with weak anion exchange chromatography. Proteome Science 2011 9:17.

\section{Submit your next manuscript to BioMed Central and take full advantage of:}

- Convenient online submission

- Thorough peer review

- No space constraints or color figure charges

- Immediate publication on acceptance

- Inclusion in PubMed, CAS, Scopus and Google Scholar

- Research which is freely available for redistribution

Submit your manuscript at www.biomedcentral.com/submit
Biomed Central 